\title{
Educational Leadership as the Impact of Teachers in the Formation of the Attitude of Students from a Manichean Perspective
}

\author{
José Manuel Castorena Machuca ${ }^{1,}$, , María Lisseth Flores Cedillo², \\ Ma. de la Luz Morales Barbosa ${ }^{2}$, Hulda Zulema delÁngel López ${ }^{2}$, Ramiro Eduardo Flores Cedillo ${ }^{3}$ \\ ${ }^{1}$ Department of Industrial Engineering, San Luis Potosi Institute of Technology, San Luis Potosi, Mexico \\ ${ }^{2}$ Department of Industrial Engineering, Higher San Luis Potosi Institute of Technology, San Luis Potosi, Mexico \\ ${ }^{3}$ Educational Technology Area, Institute of Professionalization of the Potosino Magisterium, San Luis Potosi, Mexico
}

Email address:

jmkatatcslp_01@yahoo.com (J. M. C. Machuca)

${ }^{*}$ Corresponding author

\section{To cite this article:}

José Manuel Castorena Machuca, María Lisseth Flores Cedillo, Ma. de la Luz Morales Barbosa, Hulda Zulema delÁngel López, Ramiro Eduardo Flores Cedillo. Educational Leadership as the Impact of Teachers in the Formation of the Attitude of Students from a Manichean Perspective. Education Journal. Vol. 10, No. 1, 2021, pp. 16-22. doi: 10.11648/j.edu.20211001.13

Received: December 7, 2020; Accepted: December 23, 2020; Published: February 10, 2021

\begin{abstract}
This document is about the reflection that it has fallen into a social paradigm of unwanted leadership, so it is necessary to change the paradigm of Kuhn and apply it and train young people in higher education, through Educational Institution, where values are taught and learned that must differentiate between the Nicomachean ethics and the attitudes towards the work groups that they will direct so that they take them to a state of true work teams. Some authors who use values and attitudes to establish future leadership projects are analyzed. Mention is made in the introduction and with a major emphasis on Aristotle's Nicomaquea ethics, taking into account the unseating by leaders who have given bad examples in ethics and applying a theoretical platform of the concept of educational leadership and providing what should be the educational profile with a method of analysis between ethics and values in leadership with a development focused on moral and spiritual values, and that finally concludes by contrasting the values mentioned in this article with the anti-values that educational leaders often apply in practices even if that is not their intention. In the hope in this article that this article will serve teachers and students, that the former have the role of being leaders and the latter will then be played either in their field of work, as in other communities and social interactions with the environment.
\end{abstract}

Keywords: Leadership, Values, Attitudes, Morality, Life Project, Quality of Life

\section{Introduction}

The global disenchantment over the performance of leaders, makes teachers think that in one way or another they have failed in the education of those leaders who have gone through all school levels to occupy positions of great responsibility that have often been carried out to the detriment of the followers who supported them to get to occupy positions in governments or in managerial positions.

It is worth asking, then, what has been the work of teachers in this formation of leaders, knowing that teachers are the first to instill moral values in their disciples?
Now if these students have seen good examples in their teachers, why is it that they have failed to direct their knowledge towards the common good of their followers?

This article makes a comparison of some of the best known leaders who have had a good acceptance in the execution of their leadership against others who have failed.

The subject is approached with some avant-garde positions on what good leadership should be and the conclusions are reached with some thoughts that are capable of being carried out by teachers and students.

So the objective of this article is to discover if teachers have a positive influence on instilling the necessary values in the formation of social leaders that when they leave their 
classrooms will influence on the one hand to achieve their personal goals, but on the other hand they will bring benefits. social services in their subordinates and as bosses in their selected fields of work by also exercising their academic training.

The main question posed for this paper is: Why have leaders not oriented towards the good the values that their teachers instilled in them?

Starting from the assumption that teachers form the character to a certain extent acquired in the classrooms, starting from the fact that the good is taught because the bad will be learned anywhere by the students.

This article is only based on the reflection of the performance of some of the best known leaders and that are mentioned in the development of the main theme and it is only intended to distinguish and reflect on whether the performance based on the values of universally recognized teachers have influenced or not in such a way that the students they have had have been oriented towards good or evil (according to social agreement of what good or evil is in the social contract, even if it is not in writing) in the exercise of leadership that they are trusted socially.

The word leader for the development and approach of the problem evokes the great leaders of the past like Moses to liberate the people of Israel, who were in slavery to the Egyptians, or perhaps they prefer the great Alexander the Great, Greek conqueror and disciple of Aristotle, Napoleon Bonaparte who with 2,000 men defeated 10,000 soldiers, or perhaps Gandhi with his peaceful resistance to liberate India from the British Empire, or remember Nelson Mandela, to liberate his country from Apartheid or perhaps readers of this article to Martin Luther King, with his "I have a dream" or prefers Jesus of Nazareth with a great load of moral values, congruent until death and always oriented his attitude towards the good of the entire human race in such a way that More than 2000 years have passed and his teachings are still valid and with millions of followers.

Until this moment, it is already realized that the leader first motivates with his example and can transform the attitude of others so that they pursue the dream he wants for the benefit not only of himself, but also that he will share the benefits with his followers. of that dream. In such a way that his words, his gestures, his way of dressing, of walking, his way of looking, with his gestures, that is even with his non-verbal language, convinces and captivates his followers to lead them to the fulfillment of the Vision.

The problem then is: Breaking the paradigm of corruption at least in Latin America, you can see the performance of a leader who is very liked all over the world because of his simplicity and honesty, then we talk about José Mojica, who recently ceased to be president From Uruguay. As Mojica himself says, they may criticize him; But it has shown that presidents can still live in power, with honesty that is to say "with little" and without falling into a consumerism that indebts countries and each of their citizens due to the inadequate way of exercising leadership without values or worse. with anti-values such as the bad performance (bad for those who supported them) of their presidents. It is perceived that world leaders are not satisfied with that little bit, and although at first their followers led them to occupy great positions of power, later they have repudiated them with public protests because in one way or another they took advantage of their political heights to amass great fortunes and have committed enormous injustices to their governed, in vital matters of health, education and the economy.

To mention just a few presidents eager for power and wealth, as may be remembered in the cases of Augusto José Ramón Pinochet Ugarte, in Chile, where grave and various human rights violations were committed during the dictatorship, which is why it has been criticized both in your country and in the rest of the world.

Or perhaps the case of Fidel Alejandro Castro Ruz, in Cuba, is preferred as a bad example, where due to his long tenure and the controversial characteristics of his policies, a controversial and intense debate has been generated between opponents and supporters about his government. qualify it as the exercise of a dictatorship with more than 50 years in power.

And the economic backwardness of your country?

Now there are two opposing sides of leadership, those who want to go down in history based on conquests, that is, to subjugate other peoples with the collateral damage of violence, theft of resources, be they mineral or oil extraction, crops, art, death, and with the imposition of culture, the extermination of animals, forests, in short living species, and with damage to the environment by modern weapons, whether they are sea vessels, land tanks, fighter planes, and medium missiles, long-range and even intercontinental with the use of atomic weapons with the danger of extinguishing the human race.

Does the reader notice that on the one hand there is an internal force in leaders oriented towards good?

Imagine that you were being directed by a powerful and invisible hand that moves you like puppets; but that guides them towards the good on Earth.

On the other hand if we compare other leaders oriented with anti-values in their attitudes such as Hitler, and his crematoriums in his death camps, Benito Mussolini (Il Duce = "leader"), with his dictator fascism that conquered Ethiopia (Abyssinia), and who supported another dictator that was Francisco Franco, José Stalin, with his generalized purge in the USSR, with hundreds of executions, imprisonments and confinements in concentration camps, Saddam Hussein. Who invaded Kuwait claiming ancient rights over its territory, Ayatollah Khomeni (Imam), who actively supported the actions of terrorist groups and the spread of radical Islamic fundamentalist beliefs. Which groups that followed their ideology continue to be intimidated by their threats of attacks on several countries.

At this point we want to influence the readers of this article that it is assumed that in their attitudes there is also an evil-oriented force to pursue their goals. As if a powerful force were handling them like puppets to an invisible hand that seeks power over Earth and economic, military and religious tyranny over all other human beings on the planet. And that regardless of the suffering of 
children, women, young people and the elderly, in accordance with Castorena [3].

On the one hand, you have the leaders of finance and world banks who control the military leaders and who in turn control the leaders of science and technology to apply knowledge in the development of their weapons, whatever they may these be.... The result is that only a small percentage of families dominate all human beings on Planet Earth, exploiting the labor force and destroying the natural resources of all countries and polluting their industries in the process: seas, rivers, wells, aquifers, forests, the soil, the air, and putting all living beings and even the human species in danger of extinction.

\section{Theoretical-conceptual Approach}

This article is based on the theoretical platform of some contemporary authors on educational leadership issues.

For example, about the construction of the moral personality, makes us think that values as a transversal axis are definitely what influences the achievement of the curriculum, according to Gros, B., [11].

Making it more comprehensive or holistic, in the conceptual, procedural and attitudinal, as Flores says [7].

In this field we seek to apply the methodological strategy with a focus on developing moral personality. In the always continuous search to achieve professional and social recognition.

For the above, the teacher is required to be in a permanent pedagogical renewal with conscience, commitment; but through a joint effort, in harmony with what explains Plato [17].

Applying at the same time the sociocultural models where it is concluded that the best is the Autonomous - Realist with the possibilities of acting based on reason, but also based on dialogue. And with a coherence between what is thought and what is done in accordance with Cortina [6].

Of course, the teacher is decisive for the students to make their psychological constructs to develop their moral personality with the aim of forming values that come from their family, are consolidated and increased in school and are reinforced by the social context. What makes the students reach a self-knowledge with an awareness of themselves and at the same time with a social conscience.

It goes without saying that self-esteem in students is necessary to achieve their academic success, it will also give them personal security, they will also dress with a selfcontrol that enables them to be socially accepted, which makes them generate life projects and the potential to carry them out. good term.

It is in this way that they are able to form a moral character, that you give them mental health and they form good habits with self-discipline and self-control that make them achieve their goals, in short they achieve masterful aptitude according with Gento \& Cortés [9].

All this will trigger them to dress in dialogic skills that make them grow continuously, accepting diversity and respecting human rights. Law, law and morality exist for the
State (Baruch Espinoza, 1670).

On the subject of attitudes and values applied in the educational field, perhaps the readers of this article remember, where in his theoretical contribution, interesting his proposal that they work with ethical principles where moral norms are respected, the qualities of others and achieve social agreements to develop an individual conscience and a social conscience to live in a democracy, as Castro de Bustamante says [4].

It is in agreement with, classification of values and the masterful way in which this article is based, according with jw.org [13].

Which links educational leaders or teachers with the close relationship between the attitudes and values where he rescues that actions and behaviors are shaped and regulated by norms that respond to a certain system of beliefs and values, as Bolivar says [2].

It is good that there are rules that in themselves are prescriptive; but the attitudes are required that on the one hand are acquired in the subject's previous interactions. Then come the affective and emotional charges where desires and emotions influence, then there is an assessment of the acceptance or rejection of these norms; but depending on the cognitive development of the subject until reaching social agreements.

So the educational objective is to cognitively develop students based on values so that they can accommodate their attitudes, since it reflects on what they learn and unlearn to achieve social agreements to live in peace with others.

Regarding educational leadership in the school [10], it is reflected in this article that the author is truly right that in the 80 's and early 90's the leader was considered only as a controller or as a supervisor who made sure that everything was being achieved based on what was planned, in such a way that the supervisor planned, executed and controlled.

It is the current physical and spiritual needs (Saint Augustine, the city of God) that make a strategic planning that apart from analyzing situations, to make decisions, also persuade all staff to achieve the goals and to That has to be able to manage human resources and always keep in mind that they are walking in a transformation that is permanent.

Therefore, currently the teacher leader, apart from achieving quality learning, has to be in communication with the knowledge society, meet the expectations of the students, socially consolidate the school and increase the level of autonomy of their school.

It is then taken into account that educational leadership starts from developing human capacities based on positive values and attitudes and through participatory leadership to achieve the vision and mission of the educational institution. It is worth mentioning that the types of educational leadership have to take into account in the first place the knowledge of the teaching - learning process, motivate all staff, as well as facilitate working conditions for all staff.

The leadership distributed among participating teachers must be oriented to a planned change that benefits families, students, faculty, and administrative support staff of the educational institution. 
Needless to say, it requires a moral leadership that generates trust in subordinates, based on values and attitudes, with a sense of belonging and seeking a benefit for all.

All this should bring autonomy to the work centers both in the pedagogical, as in the organizational and the management of resources.

All of the above will gradually lead to transformational leadership, where information and knowledge networks are shared, where all staff feel recognized and encouraged to motivate them towards constant innovation that leads to a process of educational quality. Hence, every educational project must be formulated based on values and clear objectives. Where there will be evaluation and accountability of these educational projects. And it causes there to be a continuous improvement based on comparing themselves with other institutions that are better until the directors are very competitive and competes to direct other schools where the role of the educational leader is more of a coach and tutor towards subordinates and to pursue this dream as utopía [15].

In a leadership approach for educational change by where this author justifies the current need for leadership in education, because achieving it leads to continuous improvement and is also a good influence, since it carries an implicit vision shared, where followers feel liberated and know that there will be a reward, the leader must reflect honesty and trust, as well as make them feel that they have the commitment, that they have control over their emotions, that they have an inner energy and optimism that They make it consistent and willing to serve, as explain Gallegos Nava [8].

It is also important in educational leadership to take into account the school management styles of Venegas \& Fernández (2008), which try to instill that it is necessary to have continuous professional training so that teachers feel identity with the educational center, because It is a psychological process of socialization where the consciousness that gives permanence and stability is enlarged, culture, history and ideology are already learned and also makes there is coherence in attitudes and values to face changes and threats.

On the other hand, the directors of the schools must take into account what are the styles of Management and Leadership, by Sánchez Manchola (2008), which tries to teach that, normally, managements use the capacities of their personnel and their virtues to achieve a positive work environment. But for that, leadership is needed based on a motivation that is inherently psychological and that directs people to where the organization wants.

These leaders that companies want, do so based on the behavior theory of Lussier \& Achua (2011) with a leadership focused on production leading people towards total performance within the organization. That is, through integral or transformational leadership with true work teams that are capable of making decisions since they are committed to achieving the goals of the organization. And it results from the work of his research that the style of leadership that gives the best results is the synergistic one since the leader makes everyone participate, makes them autonomous to self-direct and follow up on achieving the objectives.
In such a way that Leadership in education must be the educational policy priority that, on the one hand, leads to better educational practices and be willing to have shared leadership to achieve quality education.

\section{Educational Leadership Profile}

Therefore, it is required to comply with a pedagogical leader profile that is focused on a total quality system, that is effective, efficient and that contains educational quality. In addition, he must have charisma that makes him look optimistic, that makes the objectives attractive to his followers, having a sense of humor and possessing a real authority based on professionalism and legitimacy. And meet the following 6 dimensions:

1.- In the emotional dimension, you must be kind, give recognition to maintain the morale of the followers, make them feel confident, defend them, help them, anticipate problems and solve them, reflect and apply wisdom, have self-control and always put the example.

2.-In the professional dimension, it must focus on achieving educational goals and objectives, taking into account the vision, mission, consistency, resources, correcting directions and preparing strategies.

3.- In the participatory dimension, you must look for a work that is collaborative, seek the advice of experts and delegate responsibilities, as well as be willing to share authority.

4.- In the cultural dimension, look for the social configuration of the educational institution.

5.- In the training dimension: seek constant development through preparation.

6.-Finally, in the managerial dimension, carry out calls and administrative procedures that are transparent.

If these six dimensions are met, which are not really difficult, it will be possible to carry out an educational change, where there are always planned changes, with the desire for continuous improvement, with autonomy, supporting, developing and evaluating the quality of the teaching staff.. It must also be said here that we must reinforce successes and have logistical plans. At the same time to act ethically, to make the right decisions and finally to evaluate educational leadership itself socially, in harmony with Aristoteles [1].

Well so far readers think, what does that have to do with educational leadership?

Because all these leaders mentioned were forged in schools and teachers influenced their training at all educational levels they went through, first with their knowledge and with their modes of action based on moral values and some of them woke up in their students love for good, beauty and justice. Unfortunately, the social environment also educates or de-educates what students have learned in their classes.

In any case, teachers must teach their students only the good because they will learn the bad in many places (San Agustín, 420 d.c.). Even in their homes, which are firstly where they truly educate themselves and where family values 
or anti-values are also learned that spoil the efforts of the teachers in their classrooms. There are also other leaders of the sport, of the spectacles of the song, of the music, of the dance, of the religion, or even social leaders who capture them for their political or religious ideologies.

Where is the break between the values instilled by teachers and the real impact on the formation of students to be oriented towards good or evil in their attitudes in various aspects of life?

\section{Methodological Analysis}

On the one hand, the actions of the teachers are interpreted to instill values in the students and, on the other, the actions of some of the leaders who have been educated in their classrooms.

There is no doubt that Lucius Annaeus Seneca was an excellent Teacher, so why did he not impact on his disciple Nero to make him a good emperor towards good?

It is said that this teacher did influence, because Nero was moderated in the first 5 years of his government. But the moment came when the influence of bad friends and sycophants of the court was stronger, which diverted his good education towards all kinds of excesses to the point of burning a good part of the City of Rome, blaming modern Abeles, such as early Christians and sacrificing them in the circus.

Imagine if you had no education!

In the construction of more knowledge, with this article, a theoretical-conceptual approach is desired that reinforces the positive performance of teachers to dress with values that are positive and socially accepted and manifest in the curriculum they teach and that the educational authorities have given them. entrusted to transmit this knowledge and, on the other hand, use his didactic and methodological techniques in addition to his pedagogical skills for the integral formation of students, in accordance with Comenio J.A., [5].

So on the one hand, teachers in most countries are based on the following Universal values for education and the attitudinal development of their students so that they have a positive influence as citizens in their country.

In general, teachers are based on Plato's maxim in his Dialogues, to educate human beings in an integral way so that they develop all their possible potential, oriented towards good, justice and beauty [16].

In such a way that, on the one hand, all their physical potentialities are developed and for that is the practice of sport to make them agile, strong and fast.

\section{Nicomachean Ethics}

It is the part of Philosophy that looks at the value of human behavior, in this article not in the doing of educational leadership, but in doing badly or well according to social agreements. In the ever-perennial search for virtue that leads to moral perfection in accordance with Aristotle it is applied to the educational field, the spiritual or psychic side where it includes enhancing thought through philosophy and the study and learning of other sciences such as mathematics, medicine, law, astronomy and all others that have emerged and will continue to emerge in the lives of countries according to economic, political and socio-cultural needs.

Those desirable faculties in educational leaders would be the following:

1.- The ability to develop and apply intelligence: seeks the truth through the abilities to know and distinguish between the perceptions that pass through their senses and the ideas that intelligence develops.

Using a listening - thinking - writing process, organizing thoughts.

In addition to developing the capacity for reflection and synthesis.

2.- Spiritual capacity: seek the transcendence of being

Where did the human being come from?

Why are you here... on this planet called Earth?

Is there a creator?... What is his name?

What lies beyond death?

Will there ever be true and lasting peace on Earth?

3.- The ability to develop the will to achieve what we propose:

The will to power, to know and to want to do things with quality in the material and in the human, consists in seeking the good. It has been defined as "the strength of the soul that wants." The person develops to the extent that he strives to educate his intelligence and will, since they also allow him to have the ability to self-determine and choose what is most convenient to achieve the good, that is, to have freedom to do things; but with responsibility in their actions. And the only way that the will can be wrong is when an evil is chosen, with the appearance of good.

It is considered that the person does not choose an evil, by himself, because the will is not made for evil, because everything that man does is with the sincere desire to achieve a good, the difficulty is that a well; but the choice is not always correct. In this way, the will does not act alone, it wants what the intelligence presents to it. (Nobody wants what they don't know).

It is necessary to remember here what Blas Pascal (1650) says, his "You think": "The heart has its reasons that reason does not know."

4.- The ability to love:

The human being naturally leans towards the goodness and beauty of things and above all towards people, since man is a being for others. In such a way that feelings can and should be guided to better decide and with thoughtful maturity. To improve in our development as people, it is necessary to manage all the faculties of the human being in a harmonious way.

Until reaching the Christian principle of "Love your neighbor as yourself"

Thus the person is the only being that grows and seeks perfection in order to achieve it. To improve himself, he educates himself in knowledge and in the exercise of his will with response.

In the process of becoming a mature person, the individual comes to experience, in a progressive way, that within him there is an element of valuation known as consciousness. Thus, conscience is a focus of valuation that discovers the 
good. Thanks to it, the person gains confidence, makes judgments and discovers values.

Thus, one of the characteristics of the human being is that he possesses and applies the faculties of his intelligence, his will, his spirituality and his capacity to love in his daily life.

This point is strengthened since the human being is in the womb, where his life givers (energy that is already in human beings as a faculty of being transmitters of life or matter and energy because life comes from life The human being in the womb already smiles (Flores, 2017) if he is happy in that environment created for him, and if he is loved, it is communicated to him, he is stimulated by his closest relatives and he is made aware that he is loved, that he is loved, that he is told that he will be well received. Some authors call it nomic resilience, because 50\% happiness already comes in the DNA. The other $50 \%$ depends on the individual himself and the environment and society in which he surrounds himself.

"According to recent scientific studies on happiness conducted by Dasher Keltner and Emiliana Simon-Thomas, from the University of California, Berkeley, more than half of the determinants that trigger it are as internal biological factors within each person, in their DNA.

We are born happy. But there are internal factors and external factors that are shaping happiness. DNA can account for more than $50 \%$ of the determinants of happiness. $40 \%$ are internal factors and $10 \%$ are external factors. These determinants influence your happiness, positively or negatively", cited in Interconnected Circles for Well-being In accordance with Dr. Dagoberto Flores Olvera, 2017,

So use discernment the reader: if it is the opposite when conceiving a human being, if it was not desired from its conception, if it mistreats it in the womb or with the use of drugs, alcohol and tobacco and with a bad diet by Mother.

Once the human being is born in a happy family environment, he receives his first family education based on values, which will be decisive for his first school years and will facilitate the work of teachers.

And quite the opposite, if that child has not received moral values that are within the social agreement or the social contract as Jean-Jacques Rousseau says.

When the students arrive at the classrooms, the teachers will try by all possible means to influence in a positive way to shape the temperament that is inherited to a certain extent and they will shape the character of these students by dressing them with a new socially accepted personality.

In such a way then that another element that makes up the personality of a person is character, which is the same temperament but guided by intelligence and will, so it can be modified through the personal work of teachers and their own students if they have an interest in it.

Based on what values do teachers educate?

As said before, there are basically two from preschool education to higher education.

\subsection{Moral Values}

They depend on free choice. Each person is responsible for forging the virtues that allow them to live with their own moral conduct. These virtues perfect man in such a way that they make him more human.

For example, the virtue of Justice makes the person more noble, with greater dignity. On the other hand, Wealth perfects him in the material aspect, but not in his human quality.

Other virtues to consider are Prudence, Fortitude and Temperance.

\subsection{Spiritual Values}

They occupy the top of this hierarchy, since they perfect man in a superior way.

Examples of these values are: Holiness, Grace or Divine Friendship, Faith, Hope and Charity.

All values refer to human needs or aspirations. The person responds to them by acting to satisfy them, they can be classified as follows:

With this article we want to get at least to reflect with some examples of the best known of both good teachers and good leaders and bad leaders who have not been able to meet the expectations of their followers.

\section{Conclusions}

It is possible to summarize those values that the teacher educates and that the media de-educate and that become antivalues with which they will dress to exercise their leadership, be it oriented towards good or evil, (following table with words in Spanish so that readers can see its application in countries where in some way or another they speak this language).

Table 1. stock and anti-value chart in Spanish

\begin{tabular}{ll}
\hline $\begin{array}{l}\text { Cuadro virtuoso del líder en } \\
\text { base a valores orientados } \\
\text { hacia el bien social. }\end{array}$ & $\begin{array}{l}\text { Cuadro vicioso del líder en base a } \\
\text { anti valores Orientados hacia el mal } \\
\text { social. }\end{array}$ \\
\hline Honestidad & Deshonestidad \\
Hablar con la verdad & Mentira, engaño, dolo \\
Sencillez & Extravagancia \\
Lealtad & Deslealtad \\
Justicia & Injusticia \\
Humildad & Soberbia \\
Fortaleza para autocontrol & Se sale de control de sí mismo \\
Optimismo & Impositivo \\
Prudencia & Precipitación \\
Templanza & Desorden y Libertinaje \\
Obediencia & Desobediencia \\
Sinceridad & Engaño \\
Perseverancia & Inconstancia \\
Laboriosidad & Que los demás actúen en beneficio de \\
Paciencia & sus intereses personales como líder \\
Responsabilidad & Fastidio y Desesperación \\
Fidelidad & Irresponsabilidad \\
Generosidad & Infidelidad \\
Sociabilidad & Egoísmo \\
Amistad & Anti sociabilidad no dispuesto a \\
Respeto & acuerdos sociales \\
\hline
\end{tabular}

Cuadro de valores de Castorena (2014), ITSLP 
In this article, that would be the proposal as a teacher to educate based on values, in search of forming social leaders, in all fields, educational, commercial, political, military and other leaderships according to the needs of the managerial cadres of countries.

And if you dear reader of this article have the desire to be a leader:

In which painting would you like to be photographed?

Well... you have the answer!

Another conclusion is that the leader can be influenced by Machiavelli in his work the Prince in 1515 towards the bad or having as an objective that the end justifies the means.

And on the other hand, being influenced by Emmanuel Kant with his categorical imperative to see the other not as a means, but as an end himself and to enter into the other or his mystique.

And in my personal analysis I see that the results of good educational leadership will be seen in the following effect:

Where the leader is seen as an example to follow

It will be seen that the leader is trustworthy.

It will be seen that the leader is respected.

$\mathrm{He}$ is seen as a role model in society

Otherwise the leader will be seen as a liar, unfulfilled, incoherent, ungrateful. In short, he will be seen as a bad leader model to follow as an example.

Finally, if we talk about values, it must be said if we accept that we are echoes to the image and likeness of God and love (1 John 2: 8) is the most attractive quality of God (Yahweh or Jehovah), then the teachers who say Feel love for education, that is, for teaching and for the sincere desire that their students learn, it is required to transmit the content based on values and attitudes and with a focus of not only speaking to minds, but speaking from the heart of the teacher to the student's heart. The teacher who does not love his students is because he does not know God because God is love. Yes, not only with the mind, because the heart has its reasons that reason does not know (Pascal), and Gutiérrez explain [12].

For love he prepared a world before creating man and then gave him instructions so that he could live well and not die, in the same way before training the student, the teacher must prepare a whole educational world within his classroom, so that the message or content of the teaching and who knows how to awaken the interest of their students so that they learn for life and that they learn to learn (that is, they love studying, so to learn you must want to learn, and the teacher must want to teach) because learning never ends, as Marín says [14].

Love is a symbiosis Teacher - Student or teaching - learning that can be extrapolated to any place in the Universe, because wherever men come to live, they will be accompanied by the force of Ethics and values because That is why they are Universal in accordance with Kant because they make it develop and without them they will only bring destruction to other parts of the Universe.

\section{References}

[1] Aristóteles. (2010). ëtica Nicomaquea. México: Porrúa.

[2] Bolívar, A. (1995). La evaluación de valores y actitudes. Madrid: Ediciones Anaya.

[3] Castorena Machuca, J. M. (2012). Tecnoñogía Educativa en el proceso de la enseñanza - aprendizaje. San Luis Potosí: ITSLP.

[4] Castro de Bustamante, J. (2011). Educación y Valores. Educere, 1-12.

[5] Comenio, J. A. (2011). Didáctica Magna. México: Porrúa.

[6] Cortina, A. (2018). La educación en ciudadanía. Reflexión, 7196.

[7] Gallegos Nava, R. (2018). Educación Holista. Fundación Ramón Gallegos, 1-28.

[8] Gento, S., \& Cortés, J. (2011). Formación yliderazgo para el cambio educativo. I congreso INternacional RIAICES, 1-23.

[9] Goleman, D. (1995). INteligencia Emocional. Bantam books: USA.

[10] Gros, B. (2013). Retos y oportunidades del diseño participativo en tecnología educativa. Dialnet, 12-24.

[11] Gutiérrez, L. (1999). Construcción de la personalidad moral. Acción pedagógica, 1-10.

[12] jw.org. (22 de 12 de 2020). jw.org. Obtenido de https://www.jw.org/es/biblioteca/biblia/nwt/libros/: https://www.jw.org/es/biblioteca/biblia/nwt/libros/

[13] Marín, J. (2016). Guía de ética. Campus virtual, 1-21.

[14] Michel, G. (1014). Aprender a aprender. México: Trillas.

[15] Moro, T. (2011). Utopía. Madrid: Brizzolis.

[16] Platón. (2007). Diálogos. México: Porrúa.

[17] Vilo-Merino, E. s. (13 de 12 de 2018). https://riuma.uma.es. Obtenido de riuma: https://riuma.uma.es/xmlui/handle/10630/17039 